\title{
AN EVALUATION OF CONSERVATION STATUS AND ECOLOGICAL ZONATION OF ALNUS NITIDA; A MONOPHYLETIC SPECIES OF THE SINO-JAPANESE REGION
}

\author{
Z. U. Haq ${ }^{1}$, S. M. Khan ${ }^{1, *}$, Z. Ahmad ${ }^{1}$, Abdullah ${ }^{1}$, S. A. Shah ${ }^{1}$, G. Mustafa ${ }^{1}$, A. Razzaq ${ }^{2}$, F. Manan ${ }^{1}$, A. Ullah ${ }^{3}$ and \\ M. Hussain ${ }^{1,4}$ \\ ${ }^{1}$ Department of Plant Sciences, Quaid-i-Azam University Islamabad, 45320, Pakistan \\ ${ }^{2}$ Department of Botany, Islamia College University, Peshawar, Pakistan \\ ${ }^{3}$ Centre for Plant Biodiversity, University of Peshawar, Pakistan \\ ${ }^{4}$ State Key Laboratory for Conservation, College of Forestry, Guangxi University, Nanning, China \\ *Correspondence author's email: shujaqau@gmail.com; ORCID: 0000-0003-1217-6612
}

\begin{abstract}
Alnus nitida is a monophyletic species of the Sino-Japanese belt i.e., western Himalayas and Hindu Kush region. The current study was aimed to explore vegetation structure, role of edaphic and climatic factors on distribution, plant zonation and conservation status of this Alder species in the western Himalayas and Hindu Kush parts of the SinoJapanese region. The standard quadrat method was used for vegetation sampling. All the collected data were analyzed through Two-way Cluster Analysis, Cluster Analysis, Indicator Species Analysis and Canonical Correspondence Analysis using PC-ORD and CANOCO software's. Google Earth Path software (V 1.4.6) was used for the calculation of Extent of Occurrence (EOO) and Area Of Occupancy (AOO) in conjunction with IUCN red list criteria for evaluation of conservation status of Alnus nitida. A total of 146 plant species associated with Alnus nitida were reported belonging to 106 genera and 47 families from the region which clustered in 3 major zones. It was concluded that electrical conductivity, phosphorus concentration along with sandy loam soil condition and grazing pressure were the main environmental variables that play a significant role in vegetation structure, associated flora and distinct co-indicators of the Alnus nitida in the Sino-Japanese belt. The current study will provide a baseline for further comprehensive studies on Alnus nitida to explore its sustainable use and conservation priorities.
\end{abstract}

Keywords: Alnus nitida; Plants zone; Conservation Status; IUCN; Sino-Japanese; Multivariate statistics.

https://doi.org/10.36899/JAPS.2020.5.0140

Published online June 25, 2020

\section{INTRODUCTION}

Vegetation is a constitutive segment of an ecosystem that shows all the outcomes of an environment (Gray et al., 2019). Vegetation is an important part of governing the shape of an ecosystem. It reflects plant species that are in association with various environmental factors like soil, atmosphere, anthropogenic activities and other crude resources of a region. It is the outcome of habit, environmental conditions and floral composition. Vegetation shows a complex variety in a cyclic way. It starts with one season to the next and further uncovers the change in a successional path throughout the years. These changes in the vegetation complex propose a particular reaction of each plant species to the predominant natural conditions (Abbas et al., 2019; Pirini et al., 2014; Anjum et al., 2020). The vegetation of any area represents potential future changes in an area. On another hand, the sample size affects vegetation quantification (Iqbal et al., 2015). The change in sample plot size may also result in a change in vegetation i.e. appearance or disappearance of vegetation. Due to the change in sample plot size, the vegetation may transfer from positive to negative or from negative to positive. Change of sampling size and sampling procedures may result in various classifications. Likewise, vegetation shows an impact on relationship among the species aggregation or outcome.

Vegetation structure of an area is controlled by its environmental conditions like temperature, water and soil (Kumar et al., 2019). Climatic variation has a great influence on the ecosystem, especially an area which has a fragile contact between climate and ecosystem. Climatic fluctuation has a significant effect on vegetation dynamics and ecosystems at a global and local level as well (Wang et al., 2018). It provides a base for the evolutionary behavior of flora. Natural events like a progenitive cycle, the effect of abiotic factors and seedling growth (Gungor et al., 2019; Rahman et al., 2020; Shah et al., 2020), has also a great influence on vegetation structure. These changes occur during soil-plant and plant-plant interaction. It also plays a major role in territory/habitat formation for fauna. It is considered to be a system that is structured according to space, function and timing features. In the modern era, different statistical techniques are applying to analyze the vegetation dynamics (Ahmad et al., 2016). Multivariate techniques are one of them, for the classification and ordination of vegetation of an area/ecosystem. Indicator 
species of an area or community were identified while correlating plant species with environmental variables such as soil texture, EC, pH, Phosphorous, Potassium, saturation, Grazing pressure, altitude slope through these statistical packages (Ahmad et al., 2019).

A total of 5220 plant species has been documented for the flora of Pakistan (Ali, 2008; Haq, 2019). Out of which numerous plants are facing a high risk of extinction due to anthropogenic disturbances. According to (Jan and Ali, 2009) very little research documentation has been available on the threatened flora of Pakistan. However, 500 species were claimed to be threatened and needs evaluation via IUCN red list categories and criteria. The conservation status of any plant species is assessed by the IUCN red list category and criteria which predict the future and present situation of any plant in its geographical range. Alnus nitida (Himalaya Alder) is monophyletic species of the Holarctic kingdom belong to family Betulaceae. It is riparian and sometimes considers as a successional tree to initiate flora in rivers coast. Alnus nitida population is reducing in different ranges of Sino Japanese belt due to Water Scarcity Stress that leads to leaf fall and mitigate Chlorophyll contents (Davies and Zhang, 1991). The Sino-Japanese belt is bestowed with many endemic and monophyletic species; numbers of scientists are working on different aspects of such plants such as ecology, edaphology, Red listing and associations.

Alnus nitida is a monophyletic species of the Sino-Japanese region facing huge threats. Keep in view, different factors responsible for the reduction of A. nitida population in Sino Japanese belt the current study was designed. The main focus of this research work was to document, classify and quantify plant species into various associations and analyzed the influence of different environmental variables on vegetation structure and its composition. It also evaluates the conservation status of Alnus nitida in the Sino-Japanese region via IUCN Red List categories and criteria. It was hypothesized that the edaphic and climatic factors are responsible for the formation of different plant zonation associated with Alnus nitida each with distinct co-indicators. This study will provide a baseline for further research in the field of ecology especially in terms identification of ecological indicators via robust multivariate statistical approaches. It could also be used to determine the conservation status of any species in general and endemic in particular via standard IUCN Red List categories and criteria.

\section{MATERIALS AND METHODS}

The Sino-Japanese Belt: There are four Phytogeographical regions i.e., Sino-Japanese Region, IranoTuranian Region, Indian Region and Saharo-Sindian Region in Pakistan (Takhtajan, 1980). Each of the regions has been defined by certain aid of category and criteria.
The western boundary of the Sino-Japanese region is up to western Nepal and spreads up to the west limit of Himachal Pradesh (Takhtajan, 1980) (Fig. 1). It spreads through Pakistan into Afghanistan in their western limit, supported by the interruption of the high rainfall (180 $\mathrm{cm})$ regions. Before glaciation, the present Sino-Japanese flora has relatively little changed from the vegetation of the north temperate regions that surrounded the whole of the northern hemisphere (Haq et al., 2016). Flora of the northern temperate zone is one of the richest, especially in trees. Sino-Japanese elements represent $10 \%$ of the total flora of Pakistan.

Vegetation Sampling: A total of six stations (Bajaur, Dir, Swat, Buner, Hazara, and Kashmir) from SinoJapanese Region were surveyed for vegetation sampling during the years of 2017-18. Each station was further divided into different numbers of transects. At each transect, 2-5 numbers of quadrat were taken place having a size of $10 \times 10 \mathrm{~m}, 5 \times 5 \mathrm{~m}$ and $1 \times 1 \mathrm{~m}$ for trees, shrubs and herbs, respectively according to the availability of Alnus nitida species (Khan et al., 2013). The phytosociological attribute was measured for each plant species at each quadrat. All the associated plant species were identified with the help of Flora of Pakistan, skillful taxonomist and other available literature (Ali, 2008).

Soil Collection and Analyses: Soil samples were collected from each quadrat and its physiochemical properties i.e., soil $\mathrm{pH}$, organic matter, electrical conductivity (EC), soil texture, phosphorous, saturation and potassium were measured. The extracts were prepared by taking $20 \mathrm{gm}$ of soil and dissolved it in 100 $\mathrm{ml}$ of distilled water, placed on a shaker for 30-40 min at $70 \mathrm{rpm}$ and filtered into another flask through filter paper. The soil $\mathrm{pH}$ was analyzed by using 1:5 water suspensions/solution by $\mathrm{pH}$ meter. EC was measured by using 1:5 soil suspensions through conductivity meter. Organic matter was measured by the Walkley black procedure (Khan et al., 2016). The soil texture was analyzed by the hydrometer method. Available phosphorus was determined by taking a $2.5 \mathrm{~g}$ soil sample in $0.5 \mathrm{M} \mathrm{NaHCO} 3$ solutions (Iqbal et al., 2018). Potassium was determined by graph readings taken from the flame photometer.

Data Analyses: The multivariate statistical techniques were used to analyze the effect of various measured environmental factors on the distribution of associated species (Digby et al., 2012) All the data of plant species and environmental variables were put in MS EXCEL 2010 and prepared 1, 0 data for CA and TWCA of PCORD version 5 for classification of associated plant species into various association (Lepš and Šmilauer, 2003). Co-indicator species also found out using Indicator species analysis (ISA) for each zone. Canonical Correspondence Analysis and Detrended Correspondence Analysis of CANOCO software version 4.5 was used for 
ordination analysis to know about the impact of a various environmental variables on associated plant species composition, distribution pattern and abundance (Anwar et al., 2019). The treated environmental variables were aspects, altitude, grazing pressure, phosphorous, organic matter, $\mathrm{pH}$, loamy soil, sandy soil and clay soil.

Evaluation of Alnus nitida in Sino-Japanese belt: The IUCN Red List criterion (2014) was used to asses' conservation status of $A$. nitida in the Sino-Japanese belt. First of all, the area was spotted where the $A$. nitida species were present. Area covered by the species and Extinct of occurrence was measured. The local community was interviewed for the confirmation of EOO and other environmental variables affecting Alnus population in its vicinity. Initially, the GPS data was inserted in Google Earth Software and a caption was drawn from extreme points of a specific region. The Global Positioning System (GPS) data was dragged from Madyan to Marghuzar regions and AOO was recorded. The same procedure was repeated for the Dir region by dragging a line from Patrak to Timergara regions, in Buner a line from Gokand to Bekand and in Hazara from Shinkyarai to Chatti Gatti. In Kashmir and Bajaur single areas of Muzzafarabad and Barang were spotted respectively.

\section{RESULTS}

A total of 146 associated plant species of $A$. nitida were recorded belongs to 105 genera and 53 families, of which 40 were trees, 25 shrubs and 104 herbs. Floristically, family Asteraceae and Poaceae were the topmost leading families along with 13 species $(9.09$ $\%$ of the total vegetation) each followed by Rosaceae with 11 species $(7.69 \%)$. The dominant trees associated with $A$. nitida were Ailanthus latissimus, Platanus orientalis and Ficus carica with maximum Important Value Index (IVI) in the region. The rare tree species were Parrotiopsis jacquemontiana, Pyrus persica and Nanorrophs ritchiana. Arundo donax, Rubus fruiticosus and Hedra nephalensis were dominant shrubs and Berberis uliciana, Capparis spinosa and Lantana cammara were the rare shrubs associated with $A$. nitida species. Among 84 herbs, Dichanthium annulatum, Dicliptera bupleuroides and Cannabis sativa were dominant and Sorghum halepense, Lespedeza juncea and Aspidium molle were rare herb species with minimum IVI in the region.

Result of Cluster Analysis and Two-way Cluster Analysis: Clustering analysis of PCORD V5 clustered all the stations and associated flora of $A$. nitida into three different habitat types/zone/associations (Fig. 2). Twoway Cluster Analysis further comprehended the distribution of plant species in the region. The white dot shows the absence of species while the black dot shows the presence of species (Fig. 3).

Zone 1: A total of 8 stations were clustered in this zone, comprised mainly of district Swat. Top co-indicators of this zone were Celtis caucasica, Rubus fruticosus and Chenpodium murale (Table 1). These were the indicators of higher electrical conductivity and maximum phosphorus concentration along with sandy loam soil conditions. The EC ranged from 1.5-5.9 um/cm, $\mathrm{pH}$ from 6.3-7.9, Phosphorous from 4.6-10.2 ppm, potassium from 65-151 ppm, saturation from 28-52 while the soil texture was from loamy to clay loamy.

Zone 2: A total of 13 stations comprised this zone. The top 3 indicators were Eucalyptus camaldulensis, Arundo donax and Mentha arvensis under the influence of low grazing pressure, moderate phosphorus and saturated environmental variables. The $\mathrm{EC}$ of this zone ranged from 1.7-3 um/cm, $\mathrm{pH}$ from 6.5-8.2, Phosphorous from 4.8-10.1 ppm, potassium from 79-154ppm, saturation from 29-52 while the soil texture was from loamy, sandy loam and clay loam (Table 2).

Zone 3: Three stations were grouped in this zone. The topmost 3 co-indicators of this zone were Platanus orientalis, Saccharum munja and Oxalis corniculata (Table 1). These were the indicators of clay loam and low electrical conductivity environmental factors. The EC ranged from 1.7-2.1 um/cm, $\mathrm{pH}$ from 7.5-7.9, Phosphorous from 6.7-9.4 ppm, potassium from 135-145 ppm, saturation from 36-39 while the soil texture was from loamy (Table 2).

Ecological gradient through Canonical Correspondence Analysis: A significant effect of environmental data was found on species distribution pattern, composition and abundance (Table 3). The CCA (bi-plot diagram) of the first quadrant indicated that most of the plants were under the influence of phosphorous and potassium concentration, whereas the second quadrant revealed high organic matter, $\mathrm{pH}$ and saturation while in the third quadrant majority of the plants were assembled under the influence of grazing pressure, electrical conductivity and soil texture (Fig. 4).

The CCA ordination bi-plot revealed that first quadrant stations (i.e., BK-Buner, BD-Swat) are under the influence of $\mathrm{P}$ and $\mathrm{K}$ concentration, whereas the second quadrant (Br-Bajaur, TG-Dir, MZ-Kashmir, DKDir, BA-Dir) clustered under the high OM, $\mathrm{pH}$ and saturation, and few stations (AY-(Amneya) Swat, RH(Rahat kot) Swat, PD-(Pandh) Swat, KK-(Kokarai) Swat, ST-(Shoor kot) Dir, AT-(Afreen Tang) Swat, KL(Kohistan) Dir) were influenced by higher grazing pressure, EC and texture class of soil.

Population estimation: The population of mature individuals in different valleys and regions was done. 
Total estimated mature individuals were present in swat (100 in MD, 190 in RK, 170 in NK, and 120 in PD), Dir (145 in BR, 111 in GH, 50 in TG and 310 in PT), Buner (133 in GK, 15 in BK), Hazara (310 in SK, 510 in CG), Kashmir (150 in MZ) and Bajaur ( 245 in BR). According to local inhabitant of the area decline was observed in the thick forests of Alnus from the last few years due to its consumption as fuel, fodder and deforestation, along with that habitat destruction for the construction of hotels, fish farms and restaurants. Its occurrence was observed in a majority of the places of tourist spots that attract peoples. This decline satisfies the IUCN Red List Category and criteria A1 (Nature 2001)

Status summation: Alnus nitida was found in six localities i.e. Bajaur, Dir, Swat, Buner, Hazara and Kashmir. After assessing it through IUCN criteria we found it as Critically Endangered (CE) in Bajaur and Buner according to A2 (a, c, d) + B1B2 (b (i, ii, iii, iv), c (ii), Endangered in Dir according to A2 (a, c, d) + B1B2 (b (i,ii,iii), c(ii) and in Kashmir according to A2 (a, d) + B1B2 (b (i, ii, iii), c(ii), Vulnerable in Swat and Hazara according to A2 (a, d) and in Hazara according to A2 (a, d) + B1B2(b (i, ii, iii, iv), c (ii) respectively. The limiting factors for the species were Dryness of rivers/Nallahs, deforestation and habitat loss. Alnus nitida is facing critically endangered status in extreme regions of its occurrence.

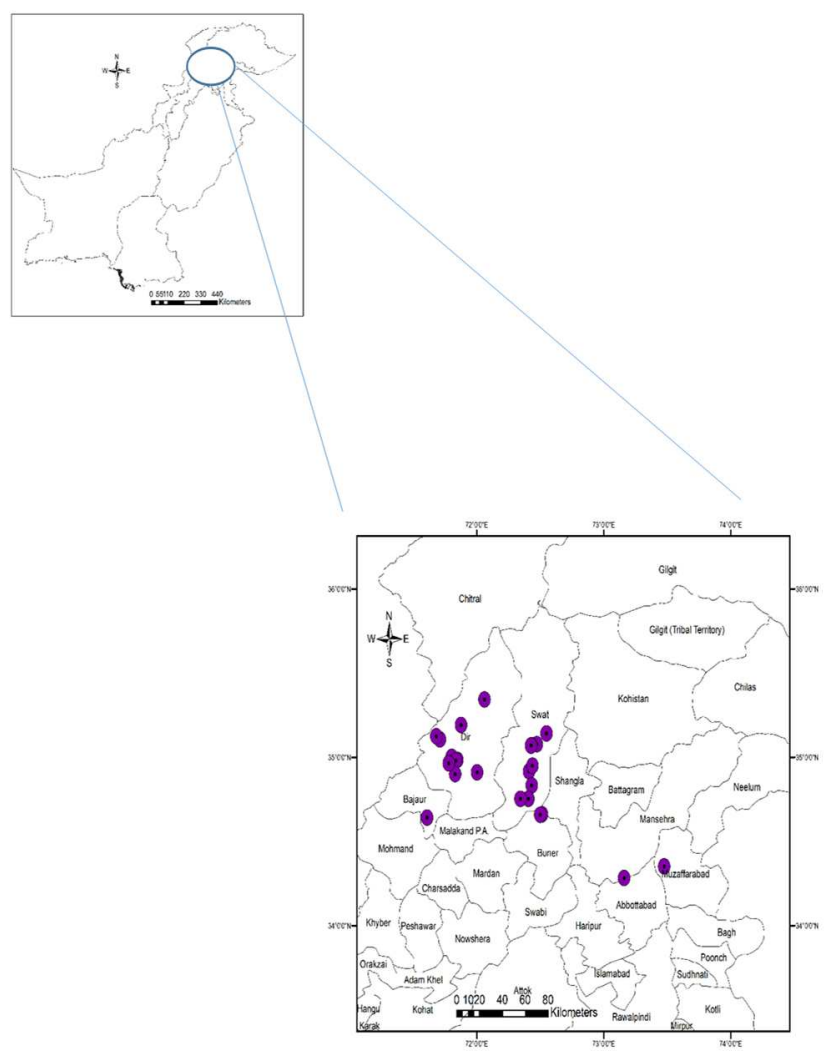

Fig. 1. The research area spotted as a blue circle on the map of Pakistan.

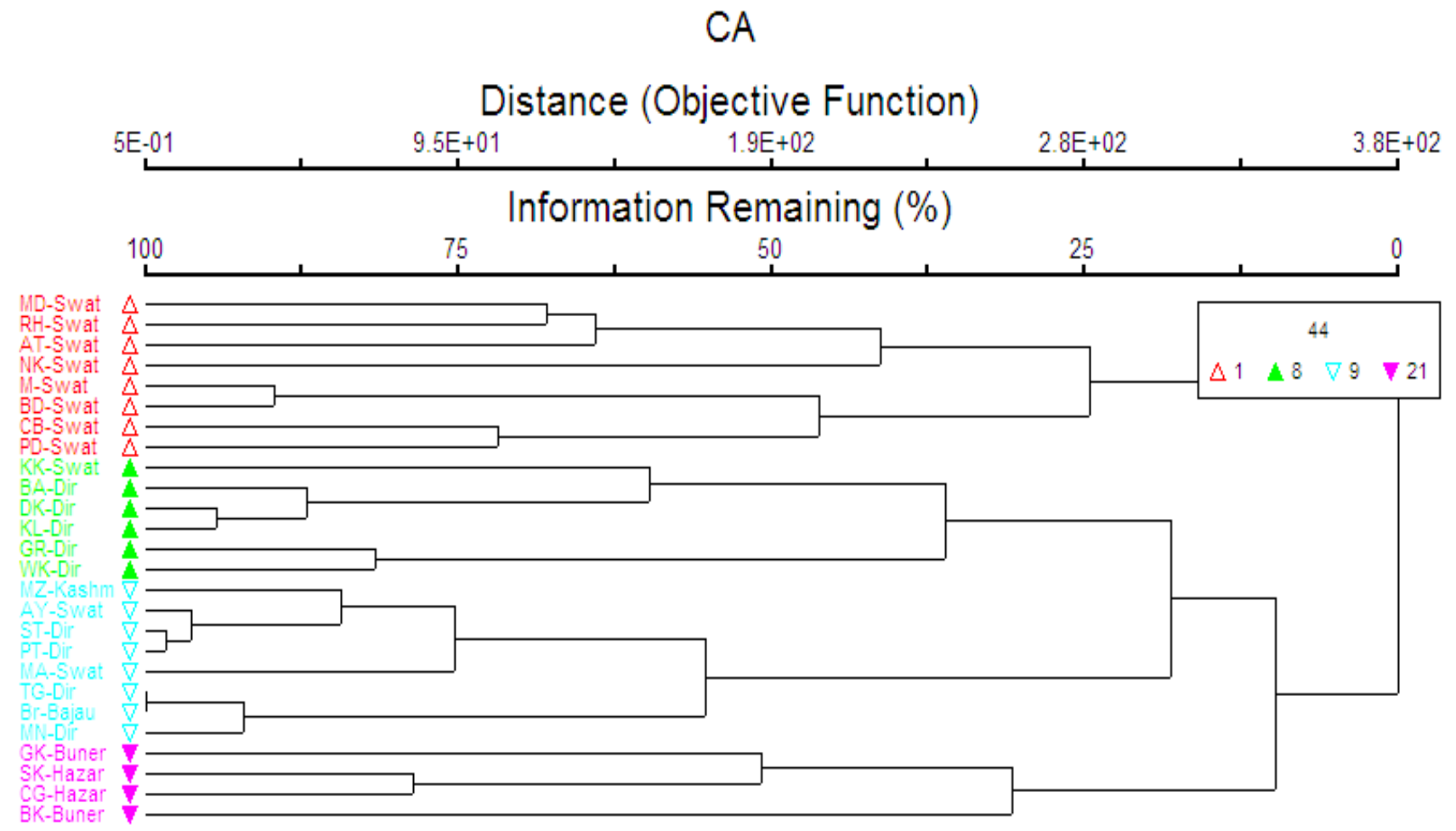

Fig. 2 Cluster dendrogram of 26 Quadrats which resulted in 3 Zones based on Euclidean measures. 


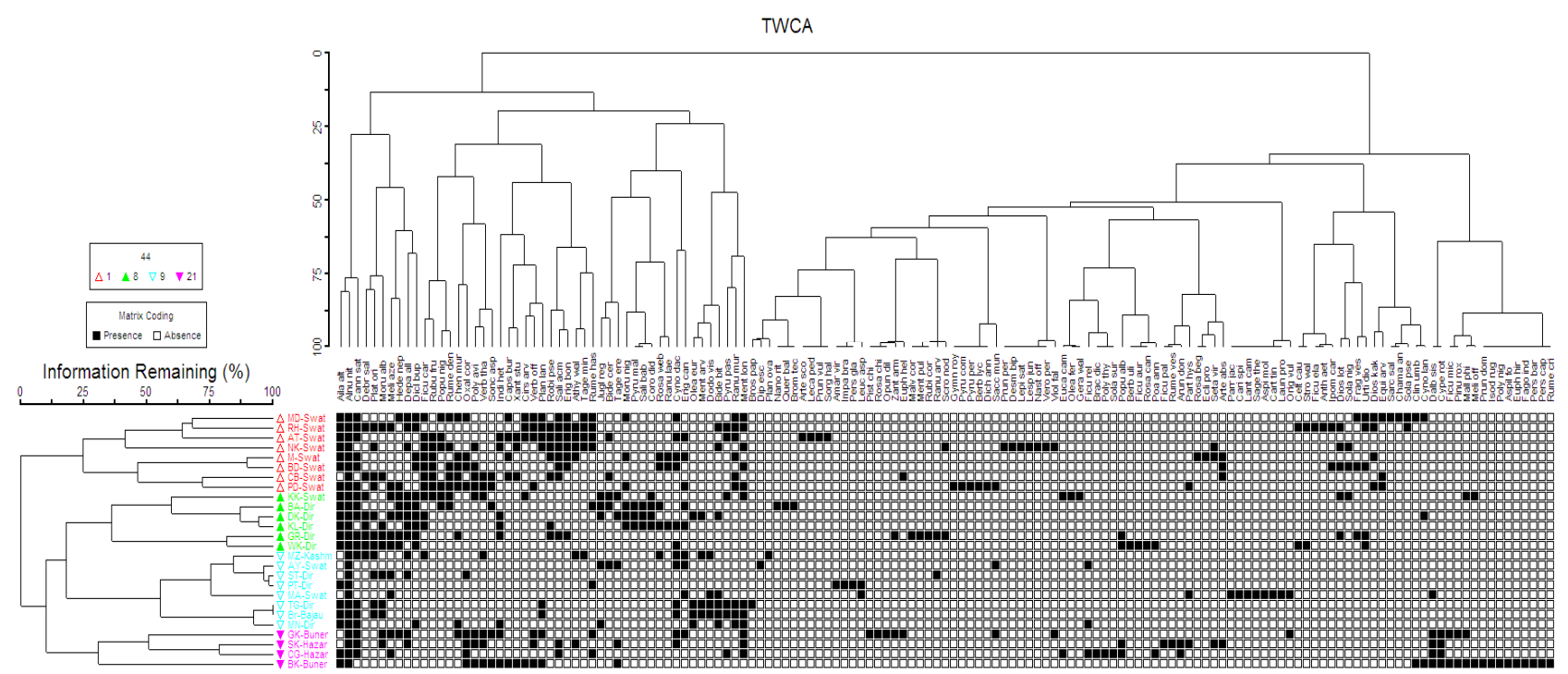

Fig. 3. The dendrogram (Two-way cluster) showing the distribution of 146 different species in the region.
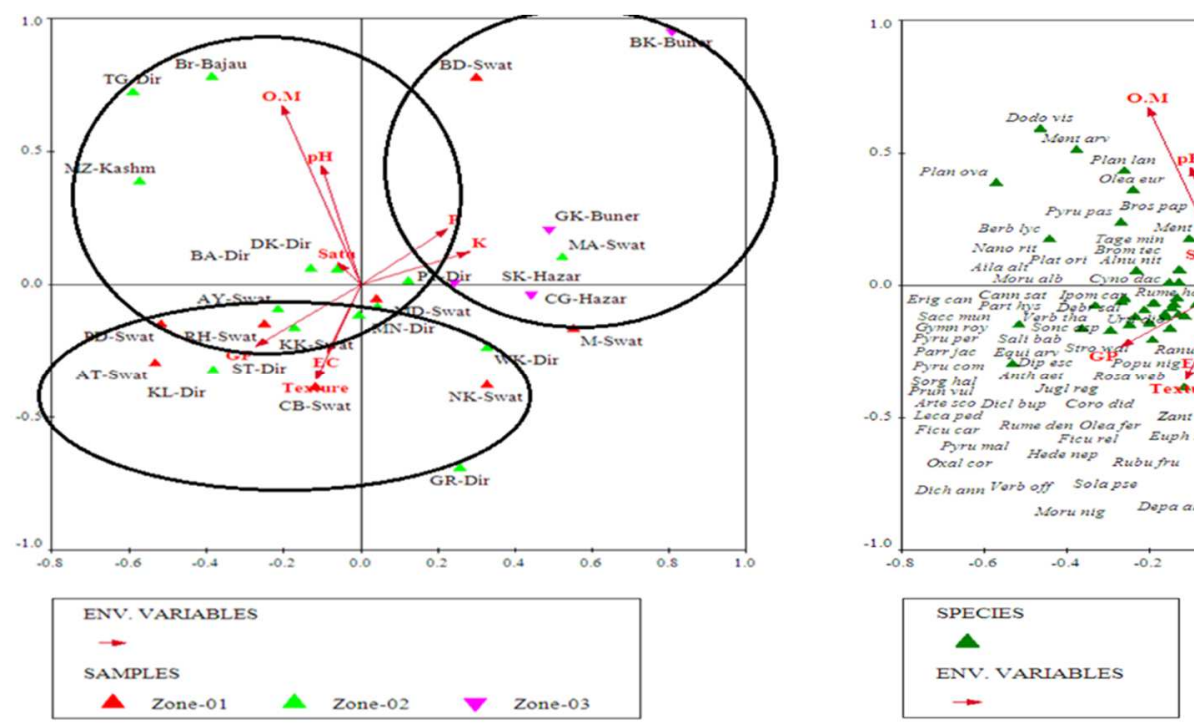

Fig.4. CCA data attribute plot shows 146 species correlation to environmental variables, where $P=P$ Phosphorous, $\mathbf{K}=$ Potassium, Satu $=$ Saturation EC $=$ Electric Conductivity, $\mathbf{G P}=$ Grazing pressure, $\mathbf{O M}=$ Organic matter and Soil tex $=$ Soil texture.

Table 1. Data summary table of $\mathbf{1 4 6}$ associated plant species in relation to all the environmental variables after CCA of CANOCO Software.

\begin{tabular}{|c|c|c|c|c|c|}
\hline Axes & 1 & 2 & 3 & 4 & Total inertia \\
\hline Eigenvalues & 0.342 & 0.268 & 0.259 & 0.230 & 4.893 \\
\hline Species-environment correlations & 0.923 & 0.917 & 0.931 & 0.926 & \\
\hline Cumulative percentage variance of species data & 7.0 & 12.5 & 17.8 & 22.4 & \\
\hline species-environment relation & 19.7 & 35.2 & 50.2 & 63.4 & \\
\hline SMC test & & & & & \\
\hline TSFCA (Test of significance of first canonical axis) & & \multicolumn{4}{|c|}{ Test significance of all canonical axis } \\
\hline Test of significance of first canonical axis: eigenvalue $=$ & 0.342 & & & & \\
\hline F-ratio & 1.127 & F-ratio & 1.027 & & \\
\hline P-value & 0.4440 & $\mathrm{p}$-value & 0.3320 & & \\
\hline
\end{tabular}


Table 2. Detail information of indicator species of all association along with significant Environmental variables.

\begin{tabular}{lllll}
\hline S. no. & Indicator species & Variables & IV & P* value \\
\hline Zone 1 & Celtis caucasica, & Sandy Loam & 40 & 0.045 \\
& Rubus fruticosus & EC & 66 & 0.049 \\
& Chenpodium murale & P & 78 & 0.015 \\
Zone 2 & Eucalyptus camaldulensis & GP & 67 & 0.01 \\
& Arundo donex & P & 51 & 0.003 \\
& Mentha arvensis & P & 60 & 0.03 \\
Zone 3 & Platanus orientalis, & Clay loam & 66 & 0.024 \\
& Saccharum munja & Clay loam & 42 & 0.034 \\
& Oxalis corniculate & EC & 61 & 0.046 \\
\hline
\end{tabular}

Table 3. Soil physicochemical analysis of each association in the studied region of Dir, Hindu Kush Mountains.

\begin{tabular}{|c|c|c|c|c|c|c|c|c|}
\hline Locality & GP & EC d/Sm & $\mathrm{pH}$ & OM \% & P mg/kg & $\mathrm{K} \mathrm{mg/kg}$ & Satu & Texture \\
\hline \multicolumn{9}{|l|}{ Zone 1} \\
\hline MD & 1 & 1.5 & 7.3 & 0.69 & 5.4 & 150 & 38 & Clay soil \\
\hline RH & 2 & 2 & 7.6 & 0.48 & 4.8 & 79 & 28 & Loamy soil \\
\hline NK & 1 & 3 & 6.3 & 0.34 & 6.3 & 91 & 32 & Clay soil \\
\hline AT & 2 & 2.7 & 7.4 & 0.69 & 4.6 & 65 & 29 & Loamy soil \\
\hline M & 2 & 1.7 & 7.1 & 0.55 & 6.3 & 80 & 28 & Loamy soil \\
\hline BD & 1 & 2.1 & 7.9 & 2.84 & 8.6 & 151 & 42 & Clay soil \\
\hline CB & 3 & 5.9 & 7.9 & 3.1 & 10.2 & 131 & 52 & Sandy soil \\
\hline PD & 1 & 1.6 & 6.8 & 0.55 & 5.4 & 85 & 32 & Clay soil \\
\hline \multicolumn{9}{|l|}{ Zone 2} \\
\hline $\mathbf{M}$ & 1 & 1.7 & 7.1 & 0.55 & 6.3 & 80 & 28 & Clay soil \\
\hline KK & 1 & 1.9 & 7.1 & 0.98 & 5.8 & 84 & 32 & Clay soil \\
\hline MZ & 1 & 2.7 & 7.5 & 4.13 & 8.4 & 154 & 52 & Clay soil \\
\hline BA & 1 & 1.9 & 7 & 1.03 & 7.1 & 79 & 32 & Clay soil \\
\hline AY & 1 & 3 & 7.9 & 0.77 & 9.1 & 104 & 38 & Clay soil \\
\hline DK & 3 & 2.1 & 8 & 0.77 & 8.7 & 137 & 40 & Sandy soil \\
\hline KL & 2 & 2 & 6.5 & 0.62 & 4.8 & 80 & 32 & Loamy soil \\
\hline GR & 1 & 2.6 & 7.4 & 0.77 & 8.9 & 174 & 49 & Clay soil \\
\hline WK & 1 & 2.5 & 7.3 & 0.55 & 5.7 & 85 & 29 & Clay soil \\
\hline ST & 2 & 1.7 & 7.7 & 0.62 & 3.5 & 143 & 36 & Loamy soil \\
\hline TG & 1 & 2.2 & 8.2 & 2.84 & 8.4 & 94 & 38 & Clay soil \\
\hline PT & 1 & 2.6 & 7.3 & 0.93 & 7.5 & 131 & 38 & Clay soil \\
\hline MA & 1 & 2.1 & 7.7 & 0.82 & 10.1 & 124 & 38 & Clay soil \\
\hline \multicolumn{9}{|l|}{ Zone 3} \\
\hline GK & 1 & 2.1 & 7.9 & 0.87 & 9.4 & 145 & 39 & Clay soil \\
\hline BK & 1 & 1.9 & 7.4 & 3.1 & 6.7 & 141 & 36 & Clay soil \\
\hline SK & 1 & 1.7 & 7.5 & 0.82 & 7.5 & 135 & 38 & Clay soil \\
\hline
\end{tabular}

Table 4. Botanical names, Family and Habit of associated with Alnus nitida.

\begin{tabular}{llll}
\hline S. NO & Family & Botanical Names & Habit \\
\hline 1 & Acanthaceae & Strobilanthes wallichii Nees & Herb \\
2 & Amaranthaceae & Achyranthes aspera L. & Herb \\
3 & & Amaranthus viridis L. & Herb \\
4 & Apocyanacae & Carissa spinarum L. & Shrub \\
5 & & Vinca rosea L. & Herb \\
6 & Araliaceae & Hedera nepalensis K. Koch & Shrub \\
\hline
\end{tabular}




\begin{tabular}{|c|c|c|c|}
\hline 7 & Arecaceae & Nanorrophs ritchiana $\mathrm{L}$. & Tree \\
\hline 8 & Araceae & Pistacia chinensis Bunge & Tree \\
\hline 9 & Aspleniaceae & Aspidium molle $\mathrm{Sw}$. & Herb \\
\hline 10 & Asteraceae & Artemisia absinthium L. & Herb \\
\hline 11 & & Artemisia scoparia Waldst. and Kitam. & Herb \\
\hline 12 & & Bidens cernua $\mathrm{L}$. & Herb \\
\hline 13 & & Bidens pilosa $\mathrm{L}$. & Herb \\
\hline 14 & & Carthamus tinctorius var. albus Alef. & Herb \\
\hline 15 & & Cirsium arvense (L.) Scop. & Herb \\
\hline 16 & & Eclipta prostrata (L.) L. & Herb \\
\hline 17 & & Erigeron bonariensis L. & Herb \\
\hline 18 & & Erigeron canadensis L. & Herb \\
\hline 19 & & Parthenium hysterophorus L. & Herb \\
\hline 20 & & Tagetes erecta $\mathrm{L}$. & Herb \\
\hline 21 & & Tagetes minuta $\mathrm{L}$. & Herb \\
\hline 22 & & Xanthium strumarium L. & Herb \\
\hline 23 & Balsaminaceae & Impatiens balsamina $\mathrm{L}$. & Herb \\
\hline 24 & & Impatiens bicolor Royle & Herb \\
\hline 25 & Berberidaceae & Berberis lycium L. & Shrub \\
\hline 26 & & Berberis ulicina Hook, f. and Thoms & Shrub \\
\hline 27 & Betulaceae & Alnu nitida $\mathrm{L}$. & Tree \\
\hline 28 & Brassicaceae & Capsella bursa-pastoris (L.) Medik. & Herb \\
\hline 29 & & Coronopus didymus (L.) Sm. & Herb \\
\hline 30 & & Lepidium sativum $\mathrm{L}$. & Herb \\
\hline 31 & & Nasturtium officinale R.Br. & Herb \\
\hline 32 & Buxaceae & Sarcococca saligna Müll. Arg. & Shrub \\
\hline 33 & Cactaceae & Opuntia dillenii (Ker Gawl.) Haw. & Herb \\
\hline 34 & Cannabaceae & Celtis caucasica Willd. & Tree \\
\hline 35 & & Cannabis sativa $\mathrm{L}$. & Herb \\
\hline 36 & Celastraceae & Gymnosporia royleana Wall. & Tree \\
\hline 37 & Chenopodiaceae & Chenopodium murale $\mathrm{L}$. & Herb \\
\hline 38 & Convolvulaceae & Ipomoea carnea Jacq. & Shrub \\
\hline 39 & Cyperaceae & Cyperus rotundus L. & Shrub \\
\hline 40 & Ebenaceae & Diospyros kaki L.f. & Tree \\
\hline 41 & & Diospyrus lotus L. & Tree \\
\hline 42 & Equisetaceae & Equisetum arvense L. & Herb \\
\hline 43 & Euphorbiaceae & Euphorbia helioscopia $\mathrm{L}$ & Herb \\
\hline 44 & & Euphorbia hirta L. & Herb \\
\hline 45 & Fabaceae & Dalbergia sissoo DC. & Tree \\
\hline 46 & & Indigofera heterantha Wall. ex Baker & Tree \\
\hline 47 & & Mallotus philippensis (Lam.) Müll.Arg. & Tree \\
\hline 48 & & Melilotus officinalis (L.) Pall. & Tree \\
\hline 49 & & Robinia pseudoacacia L. & Tree \\
\hline 50 & & Lespedeza juncea (L.f.) Pers. & Herb \\
\hline 51 & Fagaceae & Quercus baloot Griff. & Tree \\
\hline 52 & Gereniaceae & Geranium wallichianum D.Don ex Sweet & Herb \\
\hline 53 & Hamamelidaceae & Parrotiopsis jacquemontiana (Decne.) Rehder & Tree \\
\hline 54 & Juglandaceae & Juglans regia $\mathrm{L}$. & Tree \\
\hline 55 & Lamiacae & Isodon rugosus (Wall. ex Benth.) Codd & Shrub \\
\hline 56 & & Clinopodium umbrosum (M.Bieb.) Kuntze & Herb \\
\hline 57 & & Leucas aspera (Willd.) Link & Herb \\
\hline 58 & & Mentha longifolia $\mathrm{L}$. & Herb \\
\hline 59 & & Mentha pulegium L. & Herb \\
\hline 60 & & Mentha arvensis L. & Herb \\
\hline 61 & & Origanum vulgare L. & Herb \\
\hline 62 & & Plectranthus amboinicus (Lour.) Spreng. & Herb \\
\hline
\end{tabular}




\begin{tabular}{|c|c|c|c|}
\hline 63 & & Prunella vulgaris L. & Herb \\
\hline 64 & Malvaceae & Malvastrum coromendelianum Linn. & Herb \\
\hline 65 & Meliaceae & Melia azedarach $\mathrm{L}$. & Tree \\
\hline 66 & Moraceae & Broussonetia papyrifera $(\mathrm{L}$.)vent & Tree \\
\hline 67 & & Ficus carica L. & Tree \\
\hline 68 & & Ficus elastica Roxb. ex Hornem. & Tree \\
\hline 69 & & Ficus microcarpa L.f. & Tree \\
\hline 70 & & Ficus palmata Forssk. & Tree \\
\hline 71 & & Ficus religiosa $\mathrm{L}$. & Tree \\
\hline 72 & & Morus alba L. & Tree \\
\hline 73 & & Morus nigra L. & Tree \\
\hline 74 & & Ficus auriculata Lour. & Shrub \\
\hline 75 & Myrtaceae & Eucalyptus camaldulensis Dehnh. & Tree \\
\hline 76 & Oleaceae & Olea ferruginea Linn. & Tree \\
\hline 77 & & Olea europaea $\mathrm{L}$. & Tree \\
\hline 78 & Onagaraceae & Chamaenerion angustifolium (L.) Scop. & Herb \\
\hline 79 & Oxalidaceae & Oxalis corniculate $\mathrm{L}$. & Herb \\
\hline 80 & & Oxalis corymbosa DC. & Herb \\
\hline 81 & & Oxalis globosa Poepp. ex R.Knuth & Herb \\
\hline 82 & Pinaceae & Pinus roxburghii Sarg. & Tree \\
\hline 83 & Plantaginaceae & Plantago lanceolata $\mathrm{L}$. & Herb \\
\hline 84 & & Plantago ovata Forssk. & Herb \\
\hline 85 & & Veronica persica Poir. & Herb \\
\hline 86 & Platanaceae & Platanus orientalis L. & Tree \\
\hline 87 & Poaceae & Arundo donax $\mathrm{L}$. & Shrub \\
\hline 88 & & Saccharum munja Roxb. & Shrub \\
\hline 89 & & Anthoxanthum aethiopicum I.Hedberg & Herb \\
\hline 90 & & $\begin{array}{l}\text { Brachiaria dictyoneura (Fig. and De Not.) } \\
\text { Stapf }\end{array}$ & Herb \\
\hline 91 & & Bromus tectorum L. & Herb \\
\hline 92 & & Cynodon dactylon (Linn.) Pers & Herb \\
\hline 93 & & Cynoglossum lanceolatum Forssk. & Herb \\
\hline 94 & & Desmostachya bipinnata (L.) Stapf & Herb \\
\hline 95 & & Dichanthium annulatum Forssk. & Herb \\
\hline 96 & & Dicliptera bupleuroides Nees & Herb \\
\hline 97 & & Setaria viridis (L.) P.Beauv. & Herb \\
\hline 98 & & Sonchus asper (L.) Hill & Herb \\
\hline 99 & & Sorghum halepense (L.) Pers. & Herb \\
\hline 100 & Polygonaceae & Persicaria barbata (L.) H.Hara & Herb \\
\hline 101 & & Polygonum aviculare $\mathrm{L}$. & Herb \\
\hline 102 & & Polygonum thymifolium Jaub. & Herb \\
\hline 103 & & Rumex dentatus $\mathrm{L}$. & Herb \\
\hline 104 & & Rumex vesicarius $\mathrm{L}$. & Herb \\
\hline 105 & & Rumex crispus $\mathrm{L}$. & Herb \\
\hline 106 & & Rumex hastatus D. Don & Herb \\
\hline 107 & Pteridaceae & Adiantum capillus-veneris $\mathrm{L}$. & Herb \\
\hline 108 & & Adiantum caudatum Klotzsch & Herb \\
\hline 109 & & Adiantum abscissum Schrad. & Herb \\
\hline 110 & & Adiantum raddianum C. Presl & Herb \\
\hline 111 & Rannaculaceae & Ranunculus arvensis $\mathrm{L}$. & Herb \\
\hline 112 & & Ranunculus muricatus $\mathrm{L}$. & Herb \\
\hline 113 & & $\begin{array}{l}\text { Ranunculus laetus Wall. ex Hook. f. and J.W. } \\
\text { Thomson }\end{array}$ & Herb \\
\hline 114 & Rhamnaceae & Sageretia thea (Osbeck) M.C. Johnst. & Shrub \\
\hline 115 & Rosaceae & Prunus domestica $\mathrm{L}$. & Tree \\
\hline 116 & & Prunus persica (L.) Batsch & Tree \\
\hline
\end{tabular}




\begin{tabular}{|c|c|c|c|}
\hline \multicolumn{2}{|l|}{117} & Pyrus communis L. & Tree \\
\hline \multicolumn{2}{|l|}{118} & Pyrus persica $\mathrm{L}$. & Tree \\
\hline \multicolumn{2}{|l|}{119} & Pyrus malus L. & Tree \\
\hline \multicolumn{2}{|l|}{120} & Pyrus pashia Buch.-Ham. ex D.Don & Tree \\
\hline \multicolumn{2}{|l|}{121} & Rosa beggeriana Schrenk & Shrub \\
\hline \multicolumn{2}{|l|}{122} & Rosa canina $\mathrm{L}$. & Shrub \\
\hline \multicolumn{2}{|l|}{123} & Rosa chinensis Jacq. & Shrub \\
\hline \multicolumn{2}{|l|}{124} & Rosa webbiana Wall. ex Royle & Shrub \\
\hline \multicolumn{2}{|l|}{125} & Rubus fruticosus L. & Shrub \\
\hline 126 & Rubiaceae & Rubia cordifolia $\mathrm{L}$. & Herb \\
\hline 127 & Rutaceae & Zanthoxylum armatum DC. & Shrub \\
\hline 128 & Salicaceae & Populus alba $\mathrm{L}$. & Tree \\
\hline 129 & & Populus nigra L. & Tree \\
\hline 130 & & Salix acmophylla Boiss & Tree \\
\hline 131 & & Salix babylonica L. & Tree \\
\hline 132 & Sapinadaceae & Dodonaea viscosa (L.) Jacq & Shrub \\
\hline 133 & Scrophulariaceae & Scrophularia nodosa L. & Herb \\
\hline 134 & & Verbascum thapsus L. & Herb \\
\hline 135 & Simaroubaceae & Ailanthus latissimus (Mill.) Swingle & Tree \\
\hline 136 & Solanaceae & Solanum nigrum L. & Herb \\
\hline 137 & & Solanum pseudo-capsicum L & Herb \\
\hline 138 & & Solanum surattense Burm. f., Fl. & Herb \\
\hline 139 & Urticaceae & $\begin{array}{l}\text { Lecanthus peduncularis (Wall. ex Royle) } \\
\text { Wedd. }\end{array}$ & Herb \\
\hline 140 & & Debregeasia salicifolia (D.Don) & Tree \\
\hline 141 & & Urtica dioica $\mathrm{L}$. & Herb \\
\hline 142 & Verbanaceae & Verbena officinalis $\mathrm{L}$. & Herb \\
\hline 143 & & Lantana camara $\mathrm{L}$. & Shrub \\
\hline 144 & Zygophyllaceae & Fagonia cretica L. & Herb \\
\hline 145 & & Fragaria vesca $\mathrm{L}$. & Herb \\
\hline 146 & & Tribulus terrestris L. & Herb \\
\hline
\end{tabular}

\section{DISCUSSION}

Environmental variables influence the vegetation structure of an area. A total of 146 associated plants belonging to 105 genera and 53 families were recorded from 6 stations of Sino-Japanese belt (Table 4). The highest percentage of species was recorded by family Asteraceae and Poaceae having 13 species with 9.09\% share followed by Rosaceae with 11 species and 7.69\% share. Our result was in close harmony with (Khan et al., 2014) who recorded 132 plant species belonging to 104 genera and 47 families. Where, they reported Asteraceae and Poaceae as dominant families. Asteraceae is one of the successful plant family with more than 23000 species distributed all over the world (Gibson, 2009). One of the significant characters of the family is its specialized inflorescence capitulum. It attracts insects towards himself (Broholm et al., 2008). Another important character of the family is the production of seeds with lightweight, which can migrate easily from one ecological zone to another. The same pattern studies were performed by (Iqbal et al., 2018) who recorded 203 plant species belong from 70 families with Asteraceae, Rosaceae and Lamiaceae leading families. Iqbal et al.
(2015) also reported Asteraceae with 18 species and 17 genera from the adjacent Malakand region. Similar (Tesfaye, 2015) worked on Quercus glauca associated trees. Where, they reported Dalbergia sisso, Bauhania variegata, Machilus duthiei, Myrica esculentus, Pyrus pashia, Pspalum corypahaeum, Digitaria cruciata, Thalictrum foliolosum, Myrsine africana, Lonicera quinquelocularis, Caryopteris wallichiana and Deutzia staminea associated plants. The same results were also recorded by (Pagano et al., 2012) recorded 6 trees, 14 shrubs and 32 herbs in associated flora of Cedrus deodara from District Shimala. To find the floristic groups and other aspects of ecology different modern software i.e. PCORD (McCune and Mefford, 1999) CANOCO (Ter Braak and Smilauer, 2002) were used by different ecologist (Andersen et al., 2006; Pirini, 2014). The Cluster analysis, Two-way Cluster Analysis, Indicator species analysis was carried out via PCORD software to classify the vegetation into various zonation/association and its associated indicators. While CCA and DCA of CANOCO software were used for ordination analysis to know the role of different environmental variables on plant species distribution and formation of zones. A number of researchers used these 
software's for various types of ecological analysis under the influence of different abiotic and biotic factors (McCune and Mefford, 1999). During community formation, via PCORD the identical floristic communities come close enough to one another while the least identical communities are bunched as separate communities (Khan et al., 2013). All the stations and associated species were classified into three zones. The first zone clustered 8 stations with indicators species of Celtis caucasica, Rubus fruticosus and Chenpodium murale under the influence of high electrical conductivity and maximum phosphorus concentration with sandy loam soil condition. The EC ranged from 1.5-5.9 um/cm, $\mathrm{pH}$ from 6.3-7.9, Phosphorous from 4.6-10.2 ppm, potassium from 65-151 ppm, saturation from 28-52 while the soil texture was from loamy to clay loamy. Zone 2 clustered 13 stations with indicator species of Eucalyptus camaldulensis, Arundo donax and Mentha arvensis under the influence of low grazing pressure, moderate phosphorus and saturated environmental variables. EC of this zone ranged from 1.7-3 um/cm, $\mathrm{pH}$ from 6.5-8.2, phosphorous from 4.8-10.1 ppm, potassium from 79$154 \mathrm{ppm}$, saturation from 29-52 while the soil texture was from loamy, sandy loam and clay loam. The Zone 3 group based on 3 stations having indicators of Platanus orientalis, Saccharum munja and Oxalis corniculate. These were the indicators of clay loam and low electrical conductivity environmental factors. The EC ranged from 1.7-2.1 um/cm, $\mathrm{pH}$ from 7.5-7.9, phosphorous from 6.7$9.4 \mathrm{ppm}$, potassium from $135-145 \mathrm{ppm}$, saturation from 36-39 while the soil texture was from loamy. There are different reasons behind the association of species, first one was temperature harshness and secondly, different factors like EC, $\mathrm{pH}$, organic matter, potassium and phosphorus (Khan et al., 2017). The Alder species have nodules to fix nitrogen from the air which enhance the growth of plant itself as well as associated species (Kamran et al., 2018). The IUCN red list categories and criteria are the most authentic and acceptable method worldwide to find the conservation status of any species. This criterion has been updated for decades and in the present study, we applied the IUCN Red list criteria 2014 to assess the conservation status of Alnus nitida. The IUCN criteria were applied to $A$. nitida species in SinoJapanese range of Pakistan. The species was assessed as Vulnerable according to VU, A2 (a, c) A3 (c, d) +B1B2 (b (ii, iii)). Whereas VU means Vulnerable and A taxon is Vulnerable when the best available evidence indicates that it meets any of the criteria A to E for Vulnerable, and it is therefore considered to be facing a high risk of extinction in the wild. Our findings were in close harmony to Khan et al. (2013) who recorded 64 species from Naran valley where 12 species were vulnerable, 20 species were critically endangered and 7 species were near threatened by assessing it through IUCN red list criteria (A, B, C and D). Alam and Ali (2010) declared
Astragalus clarkeanus as critically endangered (CR) in Hindu Kush ranges by IUCN criteria CRB1ab (iii) $+2 \mathrm{ab}$ (iii); $\mathrm{C} 2$ (ii). The same IUCN criteria were applied by (Khan et al., 2016) who declared the endemic species of the area Berberis pseudumbellata subsp. gilgitica as critically endangered in Karakorum mountains according to criteria: 'CRA1acd; B1b (i, ii, iii) is also supporting our findings. Local inhabitants can only fully utilize the benefits of native flora if they own it and take practical steps for its conservation (Negi, 2010). The recent terminology introduced in 90's Ethno-Ecology is a famous approach for the conservation of Plant important for the ecosystem (Abdullah et al., 2019; Shah et al., 2019).

Conclusion: It was concluded that electrical conductivity, phosphorus concentration along with sandy loam soil condition and grazing pressure were important environmental variables that play a significant role in vegetation structure, associated flora of $A$. nitida and its distinct co-indicators in the Sino-Japanese belt. The Alnus species is recorded in various regions of the SinoJapanese belt of Pakistan but no comprehensive study was ever conducted on its associated species, this study will provide help to future researchers working on various aspects of Alnus nitida.

Authorship Contribution Statement: ZU Haq: Field Work, Data Collection. SM Khan: Conceptualization, analyses, Proof Reading. Z Ahmad \& A. Ullah: Formal analysis. G. Mustafa: Checking Drafts. Abdullah: Company in Field work and specimens processing. SA Shah: Identification of Plants. F Manan: Help in Soil Analyses. A. Razzaq: Help in Lab Work. M. Hussain: Statistical Analyses.

Acknowledgments: The authors would like to thanks all the members of Plant Ecology and Conservation Laboratory, Quaid-i-Azam University, Islamabad for providing every possible support during this research project. We are also thankful to the Agriculture Department Bahawalpur for helping in the soil analyses.

\section{REFERENCES}

Abbas, Z., J. Alam, S. Muhammad, R.W. Bussmann, S.M. Khan, and M. Hussain (2019). Phytocultural diversity of the Shigar valley (Central Karakorum) Baltistan, Northern Pakistan. Ethnobot. Res. Appl. 18: 1-18.

Abdullah, S.M. Khan, and Z.U. Haq (2019). The indispensable bond between Mazri Palm (Nannorrhops ritchiana) and the Indian Porcupine (Hystrix indica) leads them towards extinction!. Biodivers. Conserv. 28(12): $3387-$ 3388 . 
Ahmad, Z., S.M. Khan, E.F. Abd_Allah, A.A. Alqarawi, and A. Hashem, (2016). Weed species composition and distribution pattern in the maize crop under the influence of edaphic factors and farming practices: A case study from Mardan, Pakistan. Saudi J. Biol. Sci. 23(6): 741748.

Ahmad, Z., S.M. Khan, M.I. Ali, N. Fatima, and S. Ali, (2019). Pollution indicandum and Marble Waste Polluted Ecosystem; Role of selected indicator plants in phytoremediation and determination of pollution zones. J. Clean. Prod. 236: 117709.

Alam, J., and S. Ali (2010). Contribution to the red list of the plants of Pakistan. Pakistan J. Bot. 42(5): 2967-2971.

Ali, H., and M. Qaiser (2009). Contribution to the Red List of Pakistan: a case study of Gaillonia chitralensis (Rubiaceae). Pakistan J. Bot. 42: 205-212.

Ali, S. (2008). Significance of flora with special reference to Pakistan. Pakistan J. Bot. 40(3): 967-971.

Andersen, J.B., J. Nielsen, G. Bauch, and M. Herdin (2006). The large office environmentmeasurement and modeling of the wideband radio channel. In: Personal, Indoor and Mobile Radio Communications, IEEE 17th International Symposium on, 2006. IEEE, pp 1-5.

Anjum, S., F. Hussain, M.J. Durrani, A. Masood, A. Mushtaq, S. Rizwan, U. Jabeen, F. Bashir, and F. Behlil (2020). Floristic Composition, Ecological characteristics and Ethnobotanical profile of protected and open grazing land of Karkhasa, Balochistan, Pakistan. J. Anim. Plant. Sci. 30(2): 420-430.

Anwar, S., S.M. Khan, Z. Ahmad, Z. Ullah, and M. Iqbal (2019). Floristic composition and ecological gradient analyses of the Liakot Forests in the Kalam region of District Swat, Pakistan. J. For. Res. 30(4): 1407-1416.

Broholm, S.K., S. Tähtiharju, R.A. Laitinen, V.A. Albert, T.H. Teeri, and P. Elomaa (2008). A TCP domain transcription factor controls flower type specification along the radial axis of the Gerbera (Asteraceae) inflorescence. Proc. Nat. Acad. Sci. 105(26): 9117-9122.

climate change signal across environmental

Davies, W.J. and J. Zhang (1991). Root signals and the regulation of growth and development of plants in drying soil. Annu. Rev. Plant Biol. 42(1): 5576.

Digby, P. and R.A. Kempton (2012). Multivariate analysis of ecological communities (5): Springer Science and Business Media.

Gibson, D.J. 2009. Grasses and grassland ecology. Oxford University Press.
Gray, C.A., J.B. Runyon, and M.J. Jenkins (2019). Great Basin bristlecone pine volatiles as a

Gungor, H., Y. Çikili, and Z. Dumlupinar (2019). Evaluation of morpho-physiological traits of Turkish rice genotypes in response to salt stress under in vitro conditions. J. Anim. Plant Sci. 29(2): 556-567.

Haq, Z.U., S.M. Shah, B. Gul, A. Razzaq, and H. Raza (2016). Ecological characteristics of weeds of onion crops of University of Peshawar Botanical Garden, District Nowshehra, Paksitan. Pakistan J. Weed Sci. Res. 22(2):263-267.

Haq, Z., A. Rashid, and S.M. Khan (2019). In vitro and in vivo propagation of Monotheca buxifolia (Falc.) A. DC. An economical medicinal plant. Acta Ecol. Sin. 39(6): 425-430.

Iqbal, M., S.M. Khan, M.A. Khan, I.U. Rahman, and Z. Abbas (2015). Exploration and inventorying of weeds in wheat crop of the district Malakand, Pakistan. Pakistan J. Weed Sci. Res. 21(3): 435452.

Iqbal, M., S.M. Khan, M.A. Khan, Z. Ahmad, and H. Ahmad (2018). A novel approach to phytosociological classification of weeds flora of an agro-ecological system through Cluster, Two Way Cluster and Indicator Species Analyses. Ecol. Indic. 84:590-606.

Jan, A. and S.I. Ali (2009). Conservation status of Astragalus gilgitensis Ali (Fabaceae): a critically endangered species in the Gilgit District, Pakistan. Phyton (Horn) 48(2):211-223.

Kamran, S., S.M. Khan, Z. Ahmad, Z. Haq, and S. Khan (2018). The role of graveyards in species conservation and beta diversity: a vegetation appraisal of sacred habitats from Bannu, Pakistan. J. For. Res. 1-12. (https://doi.org/10.1007/s11676-019-00893-1).

Khan, M., F. Hussain, S. Musharaf (2014). Floristic Composition and Ecological Characteristics of Shahbaz Garhi, District Mardan, Pakistan. Glob. J. Sci. Front. Res. 1:7-17.

Khan, W., S. M. Khan, H. Ahmad, Z. Ahmad, and S. Page (2016). Vegetation mapping and multivariate approach to indicator species of a forest ecosystem: A case study from the Thandiani sub Forests Division (TsFD) in the Western Himalayas. Ecol. Indic. 71: 336-351.

Khan, M., S.M. Khan, M. Ilyas, A.A. Alqarawi, Z. Ahmad, and E.F. Abd_Allah (2017). Plant species and communities assessment in interaction with edaphic and topographic factors; an ecological study of the mount Eelum District Swat, Pakistan. Saudi J. Biol. Sci. 24(4): 778-786.

Khan, S.M., S. Page, H. Ahmad, and D. Harper (2013). Identifying plant species and communities 
across environmental gradients in the Western Himalayas: Method development and conservation use. Ecol. Inform. 14: 99-103.

Khan, T., I.A. Khan, A. Rehman, and N. Ahmed (2016). Conservation status evaluation of Berberis species across the Karakoram Mountain Ranges, Pakistan using IUCN red list categories and criteria. J. For. Res. 27(6): 1385-1390.

Kumar, V., J.C. Sharma, M. Kumar, S.K. Singh, and A. Kumar (2019). Mulches and nutrients affect the soil environment, crop performance and profitability of cauliflower. J. Anim. Plant Sci. 29(1): 194-204.

Lepš, J. and P. Šmilauer (2003). Multivariate analysis of ecological data using CANOCO. Cambridge University press.

McCune, B. and M. Mefford (1999). PC-ORD: multivariate analysis of ecological data; Version 4 for Windows; [User's Guide]. MjM software design.

Negi, C.S. (2010). Traditional culture and biodiversity conservation: Examples from Uttarakhand, Central Himalaya. Mt. Res. Dev. 30(3): 259265.

Pagano, M.C., M. Lugo, F. Araújo, M. Ferrero, E. Menoyo, and D. Steinaker (2012). Native species for restoration and conservation of biodiversity in South America Native species: identification, conservation and restoration Nova Science Publishers, Hauppauge. 1-55.

Pirini, C.B., I. Tsiripidis, and E. Bergmeier (2014). Steppe-Like Grass Land Vegetation in the Hills around the Lakes of Vegoritida and Petron, North-Central Greece. Hacquetia, 13(1): 121169.
Rahman, A.U., S.M. Khan, Z. Saqib, Z. Ullah, Z. Ahmad, S. Ekercin, A.S. Mumtaz, and H. Ahmad (2020). Diversity and abundance of climbers in relation to their hosts and elevation in the monsoon forests of Murree in the Himalayas. Pakistan J. Bot. 52(2): 601-612.

Shah, A.H., A. Mehmood, M. Farooq, K.R. Khan, B. Nawab, M. Hussain, L. Zohra, S.M. Khan, and H. Ahmad (2019). A new quantitative Ethnoecological approach to assessing the conservation status of plants: a case study of district Tor Ghar, Pakistan. Appl. Ecol. Env. Res. 17(5): 10399-10419.

Shah, S.H., N. Khan, S.Q. Memon, M. Latif, M.A. Zia, A. Muhammad, and K. Nasir (2020). Effects of auxins and cytokinins on In vitro multiplication of banana (Musa spp.) variety'W-11'in Pakistan. J. Anim. Plant Sci. 30(1):98-106.

Takhtajan, A.L. (1980). Outline of the classification of flowering plants (Magnoliophyta). Bot. Rev. 46(3): 225-359.

Ter Braak, C.J. and P. Smilauer (2002). CANOCO reference manual and CanoDraw for Windows user's guide: software for canonical community ordination (version 4.5). www.canoco.com.

Tesfaye, A. (2015). Site characteristics and regeneration studies of bani oak (Quercus glauca Thunberg) in Himachal Pradesh. PhD Thesis. Deptt. Bot. Him. Prad. Uni. Shimla, India.

Wang, F.P. (2018). Effects of land-use types on soil organic carbon stocks: a case study across an altitudinal gradient within a farm-pastoral area on the eastern Qinghai-Tibetan Plateau, China. J. Mt. Sci. 15(12): 2693-2702. 